\title{
Realizing the Comprehensive Development of Disciplines and Improving the Level of Talent Training: Taking M University's Construction of Disciplines of Marxist Theory as an Example
}

\author{
Shi-ying LU, Wei WENG* \\ Yunnan Normal University, Kunming, Yunnan, China \\ ${ }^{*}$ Corresponding author
}

\begin{abstract}
Keywords: Marxist Theory; Talent Training; Discipline Construction.
\end{abstract}
\begin{abstract}
How to develop Marxist disciplines thus has become a major question for China in the 21 st century. According to the requirements of the Ministry of Education and the Academic Degrees Committee of the State Council, considering the history and current situation of the development of disciplines of Marxist theory of M University, the Institute of Q of the university put forward the principles regarding the selection of the organization responsible for the construction of disciplines of Marxist theories, as well as concrete opinions regarding the feasibility and countermeasures for future situations, which meet the requirements for a university operating mechanism integrating scientific and technological innovation, talent training and discipline construction.
\end{abstract}

\section{Introduction}

As widely known, the reason for which "double world-class" (world-class universities and world-class disciplines) has become the most popular word is that it is not only an educational question regarding whether scientific and technological innovation, talent training and discipline construction can develop at a consistent pace with each other, but also a social question relevant to the realization of the Chinese Dream, which links with the great renewal of the Chinese nation. As Marxism is the great banner leading us to realize the Chinese dream, it is our mission in this era to develop the Marxist discipline. How to develop the Marxist discipline thus has become a major question for China in the 21 st century. It was said in ancient times that one should be down to earth so as to make some achievement. Marxism is the very down-to-earth discipline guiding our ideologies. M University, known as the "Cradle of Teachers on the Red Plateau", is one of the institutions that first began to recruit students nationwide since China's reform and opening up. Based on 30 years of development, in its province for a long period of time, the university has been ranking third in terms of the number of postgraduate students, and second in terms of the number of undergraduates. However, what we must be clearly aware of is that there still is a long way to go if we want to reach the "double world-class" goal-we need to make more progress in the construction of discipline and degree-granting points, especially in the construction of disciplines of Marxist theory, which has become a urgent need nowadays. This is because the construction of a world-class university depends on the construction of world-class disciplines, while the later depends on innovative knowledge and creative talents. In pursuing the goal, we must not deviate from the university's basic role and mission - that is to train talents and conduct scientific research [1]. As for M University, what is worth thinking about is how to develop disciplines of Marxist theory and how to make a connotative progress while following the internal logic of the scientific development.

\section{Principles Regarding Change of the Organization Responsible for Construction of Disciplines of Marxist Theory}

In terms of the internal logic of the development of a discipline, the disciplines of Marxist theory are the result of the scientific development of Marxism. The disciplines of Marxist theory are an organized form of theories, as well as a platform and a system (discipline) for academic activities [1]. Considering the history and current situation of the development of Marxism of our university, 
we should follow the four principles below in building the disciplines of Marxist theory:

The first principle is that we should take into consideration all of our university's resources when making the plans. We should start from making efforts to improve our university's general quality of the construction of disciplines of Marxist theory, and, according to the university's overall plan (top level design), establish a reasonable, stable and long-term mechanism to further improve our University's construction of disciplines of Marxist theory, while giving proper consideration and arrangement for the organization responsible and construction partners of the Marxist theory first-level discipline and its six affiliated second-level disciplines.

The second principle is that we should respect the contributions made in the past. The construction of the degree-granting points of disciplines of Marxist theory of M University began in 1993 by the application for the Master degree-granting point of "Marxist Theory and Ideological and Political Education", which was submitted by the Institute of Q and then approved. In 2006, the Master degree-granting point was divided by the Academic Degrees Committee of the State Council into two Master degree points of disciplines of "Marxist Basic Principles" and "Ideological and Political Education". Over 20 years, the Institute of Q has been undertaking main tasks in the construction of disciplines of Marxist theory; and the institute also established and trained a strong team of teachers, set the distinctive direction of research, trained more than 300 postgraduate students, and gained abundant construction experience and results.

The third principle is that we should follow the scientific law of development. The development and construction of disciplines is a systematic process in which an internal law exists [2]. A professional and scientific construction of disciplines requires an overall design covering features of disciplines, direction of research, talent training and basic conditions. What is more, it requires effective measures to ensure an organized, planned, scheduled and connotative construction of disciplines. To achieve all of this, long-term efforts and accumulated results are required. Thus in the construction of disciplines of Marxist theory we need to take into account the proper arrangement of the organization responsible, pay higher respect to the universal law of scientific development, and put great emphasis on the connotative construction of disciplines and the enhancement of the interior quality.

The fourth principle is that we should insist on cooperation. The disciplines of Marxist theory include six second-level disciplines [3]. To establish these disciplines, we need to integrate all the resources of the University, rather than only the efforts of a single institute or department, and fully utilize related institutes' experience and advantages in the construction of disciplines to achieve an integrated development, to complement each other's advantages during the joint efforts, and to make the disciplines better in terms of both quality and size.

\section{Concrete Opinions Regarding the Organization Responsible for Construction of Disciplines of Marxist Theory}

A university's construction of disciplines of Marxist theory relies on not only the design and execution of the organization responsible, but also the joint efforts of the construction partners. This principle also applies to $\mathrm{M}$ University. However, what are the concrete measures for the development? Based on the opinions and suggestions from the related departments such as the Postgraduate Student Office and the Academic Research Office of the university, taking into consideration of actual conditions, the Institute of Q put forward the following concrete opinions regarding the feasibility.

\subsection{The organization responsible for the construction of Marxist theory first-level discipline}

According to the guideline issued by the Academic Degrees Committee of the State Council, which stated that "the construction of disciplines of Marxist theory should rely on a independent second-level organization which is dedicated to education and scientific research on ideology and politics and which is under the leadership of the university to which the organization is directly affiliated, the Institute of Marxism may serve as the organization responsible for the construction of Marxist theory first-level discipline. 


\subsection{The organization Responsible for the construction of Master-granting Points of Marxist theory second-level disciplines}

Marxist theory first-level discipline includes six second-level disciplines. M University has two Master-granting points of disciplines of "Marxist Basic Principles" and "Ideological And Political Education", both of which are within the Institute of Q. Taking into consideration the University's history and current situation, for the sake of the general good and supporting the Institute of Marxism's construction of disciplines, the Institute of Q agrees on taking the department as the organization responsible for the construction of the Master-granting point of "Marxist Basic Principles", and the institute itself as the organization responsible for the construction of the Master-granting point of "Ideological And Political Education".

The reason for choosing the Institute of $Q$ as the organization responsible for the construction of the Master-granting point of "Ideological and Political Education" and for the postgraduate student training mission is as follows:

First, the Institute of $\mathrm{Q}$ has abundant experience in training academic postgraduate students majoring in "Ideological and Political Education". The institute so far has enrolled 19 classes of postgraduate students majoring in "Ideological and Political Education" since applying for the Master-granting point of "Marxist Theory and Ideological and Political Education" in 1993. And the institute also has nearly 20 years of experience in setting up majors and training talents, boasting a fully fledged operating system covering teacher teams, curriculum setting and teaching practice.

Second, the Institute of $\mathrm{Q}$ has a long history in training undergraduate students majoring in "Ideological and Political Education". The institute has provided the country with nearly ten thousand graduate students (including full-time and correspondence students) with bachelor degree and majoring in "Ideological and Political Education". The "Ideological and Political Education" major of the institute now has become the "Nationally First-class Characteristic Major" and the "Key Academic Major of Yunnan Province", being the "leading brand" of the institute and the leading role in the field of ideological and political education among all of Yunnan's universities.

Third, the Institute of Q succeeded in constructing the discipline of "Ideological and Political Education", which was listed as one of the key disciplines of the university's the 11th Five-Year Plan. In 2006, the institute applied for the construction of the discipline of "Ideological and Political Education" and got approval. After 5 years of construction, the institute passed the acceptance inspection with outstanding results in 2011.

Fourth, the Institute of $\mathrm{Q}$ is the organization responsible for training academic postgraduate students of "Curriculum and Teaching Methodology-Ideological and Political Teaching Methodology". The institute has been undertaking the mission of training postgraduate students majoring in "Curriculum and Teaching Methodology-Ideological and Political Teaching Methodology" since the university set up the Master-granting points of the second-level discipline- "Curriculum and Teaching Methodology" under the first-level discipline- "Education".

Fifth, the Institute of Q is the organization responsible for training postgraduate students of "Master of Education-Discipline Teaching- Ideological and Political Education". Since the university began to recruit postgraduate students major in "Master of Education - Discipline Teaching - Ideological and Political Education", the institute has been enrolling and training the aforementioned postgraduate students who are dedicated on-the-job education, rural education and special-position teacher on-the-job education, which include full-time and in-service students.

In conclusion, the Institute of Q is completely capable of recruiting and training the postgraduate students majoring in "ideological and political education". And if the institute undertakes the mission, it will be conducive to ensuring the quality and continuity and the construction of the discipline.

\section{Change of the Organization Responsible for the Master-granting Point of "Scientific Socialism and International Communist Movement"}

The Master-granting point of "Scientific Socialism and International Communist Movement" of 
M University currently belongs to the second-level discipline under the "Political Science" first-level discipline, which is set within the Institute of Marxism. And the Institute of Marxism is currently responsible for recruiting and training postgraduate students. As the Marxism-Leninism Department is responsible for the Marxist theory first-level discipline and for the construction of the Master point of the second-level discipline of "Marxist Basic Principles", it is suggested that the mission of recruiting and training postgraduate students majoring in "Scientific Socialism and International Communist Movement" should be shifted from the Marxism-Leninism Department to the Institute of Philosophy, Political Science and Law. The reason includes the four points below:

First, the shift is helpful for the Marxism-Leninism Department to concentrate its efforts in constructing Marxist theory first-level discipline. Marxist theory first-level discipline has six second-level disciplines: Marxist basic principles, development history of Marxism, Marxist research overseas, ideological and political education, and research on basic questions of china's modern and contemporary history. It is a heavy task to construct such number of disciplines. The shift of the mission of constructing the Master point of "Scientific Socialism and International Communist Movement" to the Institute of Q will allow t the Institute of Marxism to concentrate its efforts in constructing the five second-level disciplines other than the discipline of "Ideological and Political Education", thus providing a solid foundation and conducive conditions for the application for the Master point of Marxist theory first-level discipline.

Second, the Institute of Q is capable of recruiting and training postgraduate students majoring in "Scientific Socialism and International Communist Movement". The institute provides mediumand long-term compulsory courses of "Scientific Socialism", "International Communist Movement" and "Introduction to Mao Zedong Thought and the Theory of Socialism with Chinese Characteristics" for their undergraduate students majoring in ideological and political education. And as for the two Master points of "Marxist Basic Principles" and "Ideological and Political Education", the institute also provides the courses of "Research on Marxist Basic Principles", "Research on Sinicization of Marxism", and so on. In addition, the institute has already been authorized in 1986 the Master-granting point of the second-level discipline of "Marxist Philosophy", which involves the education and research on scientific socialism and international communist movement. So we can see that the institute has accumulated experience in the education and research on the discipline of "Scientific Socialism and International Communist Movement", and based on the its teacher team and conditions, the institute is completely capable of recruiting and training postgraduate students majoring in "Scientific Socialism and International Communist Movement", and ensuring the education quality thereof.

Third, the shit is helpful for the university to construct and apply for the Master-granting point of political science first-level discipline. "Scientific Socialism and International Communist Movement" is a second-level discipline under political science first-level discipline. The next construction goal is to apply for the Master-granting point of political science first-level discipline. And the Institute of $Q$ has been authorized to construct such Master-granting point. The institute has elaborately prepared and submitted the M University's Application for Provincial Approval and Support on the Construction of the Master-granting Point of Political Science First-level Discipline in May, 2011, according to the requirements of the Notice by the Yunnan Academic Degrees Committee and the Yunnan Education Department on Initiating the Construction of Degree-granting Disciplines and Provincial Key Disciplines According to the 12th Five-Year Plan (document code: Yunxuewei [2011] No.7).

Fourth, the Institute of Q meets the basic conditions for the construction of the Master-granting point of political science first-level discipline. The institute has created the Department of Political Science - an entity for political education, which currently is staffed with 20 full-time teachers, including 4 professors, 6 associate professors, 11 doctors and doctoral candidates, meeting the requirement in terms of teachers for the construction of political science discipline. What is more, the institute has also set up the Research Center of Science of Politics and Public Administration, which caters to the needs of academic research on political science.

Besides, considering the University's arrangement for degree-granting points, the Institute of Q 
decided to waive application for the Master-granting point of political science first-level discipline, mainly in order to enhance the connotative construction of the existing disciplines [4].

\section{Concrete Suggestions Regarding the Application for the Degree-granting Point of Marxist Theory First-level Discipline}

To complete our university's construction of disciplines of Marxist theory, we should apply for the Master-granting point of Marxist Theory First-level Discipline as soon as possible. The suggestions are as follows:

First, the application for construction of the Master-granting point of Marxist theory first-level discipline should be prepared under the leadership by the Institute of Marxism and the joint efforts by the Institute of Q, and submitted as soon as possible. According to the analysis report provided after the third round of discipline assessment conducted by the Ministry of Education in 2012, we should further improve contents of the discipline and integrate resources to build academic teams while meeting all the requirements for construction of the first-level discipline. And we should also perfect our training plans to distribute related responsibilities to individuals and to make more detailed the core indexes for evaluating matters related to discipline construction, such as papers and monographs to be published, and research topics and results to be awarded.

Second, the construction mission of five research subjects (academic majors): "Marxism Basic Principles", "Development History of Marxism", "Research on Marxism Overseas", "Research on Sinicization of Marxism" and "Research on Basic Questions of China's Modern and Contemporary History" should be undertaken by the Institute of Marxism.

Third, the construction mission of the research subject (academic major) "Ideological and Political Education" should be undertaken by the Institute of Q. If the Master-granting point of "Marxist Basic Principles" is shifted to the Institute of Marxism, on the one hand, it will be a beneficial solution for the institute to keep its teacher team's stability and discipline-related advantages, and on the other hand, as for those teachers who has been teaching and doing research on Marxist theory in the institute, the shift will solve the question of what would these teachers do in the future and allow these teachers to continue to contribute to the university's construction of disciplines of Marxist theory.

Fourth, it is about the distribution of responsibilities and missions after the application for construction of Marxist theory first-level discipline is approved. After the application is approved, based on the tasks completed by the Institute of $\mathrm{Q}$ and the Institute of Marxism during the application, respectively, the two institutes should continue to develop their respective disciplines.

\section{Acknowledgments}

The paper is supported by graduate education and teaching reform project of Yunnan Normal University (YJG2015-D03).

\section{References}

[1] Gao Guijuan. An Enlightenment from Karlsruher Institut für Technologie, Germany: How Does the World-Class University Promote Its Development of Fist-Class Discipline [N] Wen Wei Po, 2017-6-23 (6).

[2] Ghao Wenping. Research on the Law of Discipline Development and the Issues in Discipline Construction [J]. Academic Degrees \& Grduate Education, 2004 (5): 23-26.

[3] The Notice about Regulating and Adding the Marxist Theory First-level Discipline and Its Affiliated Second-level Disciplines (document code: Xuewei [2005] No. 64).

[4] Liu Xianjun. On the Discipline Construction of Universities [J]. Research on Higher Education, 2000 (5): 16-20. 